\title{
Where Should the Money Go? A Six-country Comparison of Attitudes toward Spending on Public Pensions and Unemployment Programs
}

\author{
JoEllen Pederson
}

Correspondence: JoEllen Pederson, Department of Sociology, Anthropology, and Crimnal Justice Studies, Longwood University, Farmville, VA, USA.

\author{
Received: August 10, 2013 Accepted: September 3, 2013 Available online: October 21, 2013
}

doi:10.11114/ijsss.v2i1.240 URL: http://dx.doi.org/10.11114/ijsss.v2i1.240

\begin{abstract}
Using both country-level and individual-level theories and indicators, this paper examines attitudes toward government spending on unemployment and pensions, two of the most expensive welfare state programs. I use a basic form of multilevel modeling to test three theories: self-interest, political ideology, and Esping-Andersen's regime typology. Specificlly, I examine how self-interest and political ideology shape respondents' ideas about spending on welfare and how these ideas vary across six countries. Based on my results, I argue that attitudes toward unemployment and pensions are not the same and cannot be assumed to be. With that said, Esping-Andersen's typology can, in fact, be applied to attitudes with minimal variation especially as it pertains to pensions. Self-interest and political ideology theories both impact individual-level differences in attitudes; while these theories measure different ideas of influence, they are both important in understanding peoples' attitudes about social policies.
\end{abstract}

Keywords: welfare, pensions, unemployment, cross-national, public opinion

\section{Introduction}

Public officials often use attitudinal data to make claims about what should be done to public policy. This matters because, if polls are not examined carefully, reformers can make assertions without proper evidence (Cook \& Jacobs, 2002). Based on the evidence from the data analyzed in this paper, it is clear that public pensions and unemployment programs supported by government funding are still highly favored in the six countries analyzed (the United States, the United Kingdom, France, Germany, Denmark and Sweden). However, clear differences emerge on both the individual and country-level depending on if respondents are asked about pensions or unemployment. These patterns reflect values held by individuals within and between countries in regard to government spending on elderly populations versus unempoloyed populations. To understand the individual and country-level differences in attitudes, this research uses established individual-level theories (self-interest and political ideology) and re-exames the importance of Esping-Andersen's (1990) regime typology.

To the extent that some groups benefit more than others, welfare states create cleavages and conflict structures. This means that individual preferences for social policies can be influenced by the degree of social risk for needing those benefits. From this perspective, policy attitudes should be based on perceived risk with those who are most likely to depend on social programs being more supportive than those who are less likely to do so. I operationalize this idea using the self-interest theory. As an alternative view to how individual preferences for social policy devlelop, researchers have suggested that one's political ideology will dictate how they make complex policy decisions. Thus, it is less about how people will be influenced by the policy and more about their allegiance to an idea. To bridge the divide between these two theories, I study both simultaneously, which has rarely been done (see Quadagno \& Pederson, 2012, for exception). On a national level, welfare states have been best understood using Esping-Anderson's (1990) typology. This typeology suggests that welfare states can be categorized as liberal, conservative, or social democratic. In this paper, two countries are used as 'ideal types' to represent each regime. The United States and the United Kingdom represent the liberal regime, Sweden and Denmark represent the social democratic regime, and France and Germany represent the conservative regime. Previous research has argued that Esping-Anderson's typology is fairly accurate at deciphering welfare states, except when it comes to understanding attitudes (Svallfors, 2004). I argue that the way in which the typology has 
been applied to attidues in previous research may not fully test how well this typology can explain attitudes.

Based on these previously established theories and the data available, this paper addresses the following questions: What individual-level predictors best explain variations in individuals' attitudes toward the financing of the welfare state in the six aforementioned countries? Are these predictors different when respondents are asked about pensions versus unemployment benefits? Are there regime-level variations on attitudes about public pensions and unemployment when each program is examined independently? To address these questions I use data from the 2006 Role of Government wave of the ISSP (International Social Survey Program). The research questions are addressed using multilevel regression modeling in Stata 12.

\section{Relevant Scholarship}

There are four main dimensions of the welfare state where attitudes are relevant: the functions of the welfare state; the means of the welfare state; the effects of the welfare state; and the financing of the welfare state (Andreß \& Heinen, 2001). The purpose of this paper is to examine attitudes about the financing of the welfare state. To explain attitudes on an individual-level, self-interest and political ideology theories are explained.

\subsection{Self-Interest}

Researchers have long posited that self-interest affects opinion of government policies. For example, in both sociological and economic theory, Marx (1887/1927) discusses self-interest in terms of materialist theory; then, Weber (1921/1968) debates self-interest in terms of instrumental rationality (Breznau, 2010). I use the term self-interest to describe an individual economic response to welfare state programs. Ideas similar to self-interest have been called things like social risk (Quadagno \& Pederson, 2012) and situational factors (Blekesaune and Quadagno, 2003). This economic approach asserts that attitudes originate from individual's calculations on what policies will have the most personal benefit to them. This benefit can come in the form of receiving social assistances, paying lower taxes if programs are cut, or working in the social service sector (Andre $\beta$ \& Heien, 2001). As such, people are less likely to favor policies that hurt them financially or where they feel their economic loss does not outweigh the social gains (Brooks \& Manza, 2007). In The Velvet Glove, Jackman (1994) states that in politics, one group can only benefit when another group looses power or control. Under this concept, all groups are comprised of people who, "strive to maximize their control" (page 3). Thus, she assumes that people are always self-interested.

Self-interest theory is situated in the idea that people will favor policies that benefit them financially; therefore, it is reasonable to presume that socioeconomic status would have a significant impact on welfare policy preferences. Rueda and Pontusson (2010) examine how social class matters for welfare attitudes. They find that the wealthiest respondents are least likely to support redistribution, but the poorest respondents are not necessarily the most likely to support it. How people identified their own social class impacted their attitudes; not identifying as "poor" or "in need" changed attitudes in the lower classes regardless of actual income (Rueda \& Pontusson, 2010).

Svallfors (1997) and Hansenfeld and Rafferty (1989) examine support for various social programs based on class and status groups. They find that those using welfare programs or those who are at risk of using programs have more favorable attitudes. In contrast, those who felt their taxes were being used for such programs have less favorable attitudes regarding programs supporting the poor or unemployed. Another study that examines the self-interest theory in terms of socioeconomic status finds that those who are unemployed are more likely to favor unemployment programs (Gelissen, 2000).

Age has also been considered an element of self-interest for programs that are age specific, like public pensions for the elderly. The elderly should have the most favorable attitudes toward social security, because they directly benefit from the program. Several studies have tested this idea. Canaan et al. (1993) find that age (used as a socio-demographic variable) helps explain variation in attitudes toward different welfare state programs. Anderson (2002) finds some support that age plays a role in attitudes but not necessarily for pensioners. In his study of Norway and Denmark, he finds that age was not a determinant of attitudes toward health care or pension programs. He did, however, find some age variation in attitudes for programs such as childcare and nursing homes. Typically, younger people were more supportive of childcare programs while older people favored nursing home programs. In yet another study that examines the affect of age on attitudes toward welfare, Busemeyer, Goerres, and Weschle (2009) test the relative impact of age on individual attitudes toward welfare policies in 14 OECD countries. They find that in some cases age was a better predictor of welfare state attitudes than income, and thus, conclude that one's position in the life cycle is more important than income in determining what programs a person is likely to support. 
Gender ideologies have also been considered as an aspect of the self-interest theory. Studies find that typically women are more likely to support welfare programs than men. Women are more likely to support public pensions because they have longer life expectancies than men and thus benefit longer from pension programs. Women are also more likely to have pubic pensions as their sole source of income (Svallfors, 1997; Quadagno \& Pederson, 2012). Linos and West (2003) find that "gender matters" when examining support for welfare redistribution. In numerous countries, women are slightly, but significantly more likely to support redistribution. Linos and West offer several explanations that coincide with the self-interest theory, including the fact that more women are welfare-state employees, and that women are more disadvantaged by the labor market and, therefore, in greater need of state benefits.

Self-interest theory is, in some regards, difficult to test because respondents have to determine how they feel about spending money on programs they may or may not benefit from while also balancing how they feel about spending money for the common good. Previous researchers use this theory to understand why people support certain policies (or candidates who support policies). Other researchers, however, are less convinced that self-interest is what determines attitudes toward policies. For these researchers, self-interest falls short for several reasons, including the fact that people may not know or care much about a particular policy. If this is the case, what determines attitudes and voting preferences? To address this rebuttal, researchers have proposed political ideology as an alternative theory.

\subsection{Political Ideology}

The embedded preferences/political ideology theory examines attitudes in regards to welfare state policies on an individual-level and has been tested in a cross-national context. According to the political ideology approach, attitudes toward the welfare state are influenced by basic value systems and by ideological predispositions, which help voters make sense of complex policy options (Lynch and Myrskyla, 2009). The political ideology approach understands the origins of such attitudes to be rooted in ideological preferences, social identities, and institutional environments. More specifically, attitudes toward the welfare state are rooted in values regarding the proper relationships between the individual, the state, and various institutions (Brooks \& Manza, 2007; Blekesaune \& Quadagno, 2003).

Political ideology is measured in several ways in the welfare state literature. Liberal/left party preference is one variable that researchers have used to operationalize this theory. Jaeger (2006) finds that left party preferences increased support for redistribution, while a conservative/right party preference has no effect. Jacoby (1994) uses party identification and a measure of liberal-conservative self-placement to measure American's beliefs about ten different government programs, including welfare programs and non-welfare programs. He finds that both party identification and the measure of liberal-conservative placement has a significant effect on attitudes toward government spending on both types of programs. Brooks and Manza (2007) use this theory to investigate whether welfare state programs are likely to converge as nations face rising public budgets and a need for retrenchment. They find that the public (both right-leaning and left-leaning) is opposed to welfare state retrenchment, which gave elected officials pause when trying to cut programs for fear of retribution by voters. The relationship between history, politicians, and voters' attitudes is intertwined in a way that makes each country's welfare state unique. Egalitarian attitudes have also been used as supplements to political ideology theory. Those with higher levels of egalitarian attitudes have more favorable attitudes toward welfare state programs. Blekesaune and Quadagno (2003) find that egalitarian attitudes at both the individual and state level mediate self-interest characteristics like age in regards to attitudes toward welfare state programs for the elderly.

\subsection{Regime Theory}

Some researchers use regime theories to understand welfare state attitudes. A regime is a cluster of countries that share similar characteristics. The most well-known typology in the welfare state literature was created by Esping-Andersen (1990). It quickly became a contemporary classic. In his typology, countries are clustered into three regimes: liberal, conservative/corporatist, and social democratic.

Liberal welfare states have universal social insurance systems to compensate for income loss due to unemployment and old age, but they rely heavily on targeted benefits for the "deserving" poor, namely single mothers and the aged. They also favor the market for the provision of services and are less likely to use the tax system as a mechanism for redistributing wealth. The United Kingdom, Canada, Australia and the United States are typically included in this regime type (Arts \& Gelissen, 2002; Esping-Andersen, 1990; Korpi \& Palme, 1998; Svallfors, 1997).

Conservative welfare states originated in nations with Christian Democratic parties, where the political ideology is deeply rooted in Christianity (Hicks, 1999). A key tenet of conservative nations derives from the Catholic interpretation of justice: the more fortunate have a responsibility to help the poor. Conservative nations also 
adhere to the principle of "subsidiarity," meaning that the government should only intervene in the functions that the local family or voluntary organizations, particularly church-related organizations, cannot perform. When these principles are embedded in welfare states that reproduce the existing class structure and that preserve the male-breadwinner family, they are reflected in policies that emphasize local responsibility. An example of the preservation of the male-breadwinner system is a preference for direct cash transfers over public services, such as day care, that might promote women's labor force participation (Esping-Andersen \& van Kersbergen, 1992; Huber \& Stephens, 2000; Huber, Ragin \& Stephens, 1993; van Kersbergen, 1995). France, Germany, and Italy are among the countries classified as conservative.

Social democratic regimes are notable for their preferences toward universal welfare programs, their emphase on social equality, and their rejection of means-testing as a criterion to determine eligibility for benefits (Arts \& Gelissen, 2002). Programs are designed to provide a high quality of services and to promote employment opportunity, not merely to prevent destitution (Olsen, 1998). This regime is known for providing high levels of de-commodification for their citizens. This has been suggested to build cross-class solidarity, because everyone is benefiting from the same welfare state policies. These countries are also noted for their programs that help create full employment in the labor force. The social democratic regime is the smallest of all three regimes. Included in this regime type are Sweden, Denmark, Norway, and other Nordic countries (Esping-Andersen, 1990).

Esping-Andersen based his typology on key variables that can be found in unemployment and pension systems. Specifically, to measure de-commodification he combined three de-commodifiction indexes. The first is based on pension systems. For each country, he quantified four variables of the pension system: the minimum pension benefits for a standard production worker earning an average wage; the standard pension benefit for a normal worker; the contribution period required for a standard pension; and the individual's share of pension financing. He created a ratio based on these numbers. He then compared this ratio to another ratio he created that took into account the similar elements between unemployment benefits and sickness benefits. These ratios helped Esping-Andersen place countries into one of the three regimes. It is fitting, then, that I examine attitudes about two of the three welfare state programs, which were used to create the typology to test how relevant the typology is for attitudes specifically.

Many researchers have tested Esping-Andersen's typology with economic or political variables with moderate success, although most suggest the addition of another regime (see Arts \& Gelissen, 2002, for summary). Critics have argued that Esping-Andersen's typology is inadequate for identifying the core characteristics of many welfare states: that there are actually four or more regimes types (Svallfors, 1997); and that "real welfare states are hardly ever pure types and are usually hybrid cases" (Arts \& Gelissen, 2002:137). Further, feminist theorists have noted that regimes based on a particular configuration of class relations cannot account for the way social programs structure gender relations (Lewis 1988; O'Connor, Orloff and Shaver 1999). Despite these criticisms, the notion that welfare states are organized around certain distributional principles has been remarkably enduring.

Recently, researchers have started to apply this classic typology to explain welfare state attitudes. Basically, such application furthers the idea that country-level variations in attitudes about welfare exist and that national level variations are determined by the regime in which a country is classified. The results of these empirical tests have been mixed.

Svallfors (1997) examines how well attitudes match Esping-Andersen's (1990) typology. He finds that attitudes do vary by country and sometimes correspond to Esping-Andersen's typology. In social democratic countries, for example, people had more favorable attitudes toward redistribution.

Andreß and Heien (2001), using attitudes as a dependent variable, examine East Germany, West Germany, Norway, and the United States to test Esping-Andersen's regime theory. They find that unless both country-specific and aggregate-level effects were included, only an incomplete picture of welfare state attitudes emerges. Based on their test of the regime theory, the lowest levels of support exist in the liberal country (the United States), moderate levels of support exist in the conservative country (West Germany), and high levels of support exist in the social democratic country (Norway). Interestingly, the highest levels of support are present in East Germany. The authors attribute this presence to the communist past of this country, which still influences social policy attitudes.

Others are even more skeptical about applying regime theory to understand attitudes. Using the 1985 and 1990 ISSP-Role of Government surveys, Bean and Papadakis (1998) find very limited support for the link between attitudes toward welfare and regime type. Jeager (2006) argues that one reason Esping-Andersen's regimes do not work with attitudinal data is because the regimes have not been operationalized correctly. Testing countries 
that exemplify regimes using the program that was originally used to create the regimes is a logical step in seeing how well the regime hypothesis can explain attitudes. Therefore, instead of using as many countries as possible which admittedly results in more statistical variation and thus more advanced multilevel modeling techniques - I am using six countries that represent ideal types of the three regimes. My two liberal countries are the United States and the United Kingdom. I use Sweden and Denmark to represent the ideal types of social democratic countries. Lastly, I use France and Germany to represent corporatist or conservative countries. I am not the first researcher to use this technique. While it is true that no welfare state is entirely unique or entirely similar, the use of ideal-types has been recognized as a way to make conceptual comparisons and also develop theoretical statements (Arts \& Gelissen, 2002). Andreß and Heien's (1999) article provides an example of this type of research, where three countries are used to examine the differences in attitudes by country.

\subsection{Hypotheses and Their Correspondence to Research Design}

The research mentioned above does not specifically examine public pensions or unemployment in terms of the Esping-Andersen typology. By operationalizing this regime using six "ideal-type" countries (two for each regime) and public pensions and unemployment benefits as the indicating variables, I expect that there will be a significant difference between social democratic, liberal, and corporatist nations. My first hypothesis, therefore, is that I expect social democratic nations to show more support for government spending than liberal and corporatist/conservative countries. I also expect liberal countries to have the least support for government spending. This is partially because the United Kingdom has already implemented policies that reduce government responsibility for pension benefits. On the individual-level, I expect women and those who consider themselves to have low incomes to have higher support for spending on pensions and unemployment. I also expect the unemployed to have favorable attitudes toward spending on unemployment and elderly people to have favorable attidues toward pensions. Thus, my second hypothesis is that self-interest theory will be supported. For my third hypothesis, I expect to find support for the political ideology theory. Specifically, I think left-leaning citizens in every country will have more favorable attitudes toward welfare spending on both programs.

\section{Data and Method}

\subsection{Data}

This paper uses the 2006 wave of the International Social Survey (ISSP), which focuses on the role of government. The ISSP is ideal for this study because it combines multiple country-level surveys into one comparative dataset that is publicly accessible. It is deemed one of the most reliable datasets of this type. The ISSP was formed in 1980 out of collaboration between four national surveys (including the General Social Survey in the United States). It has grown to 48 nations as of 2009. Each country is responsible for collecting and funding their own data collection. The collaboration between the national organizations associated with the ISSP is routine and continual, making this international data set useful for both time and cross-national comparative work.

This data is also ideal because previous waves have been used for investigations similar to this project. Blekesaune and Quadagno (2003) used the 1995 ISSP data to examine how situational and ideological factors affected attitudes at both the country and the individual-level. This study analyzed data from 23 countries that pertained to programs for the unemployed, programs for the sick, and programs for the elderly. The current project mirrors Blekesaune and Quadagno's theoretical model on individual attitudes but uses fewer countries to facilitate testing Esping-Andersen's typology specifically. This study also uses methodological elements from Busemeyer et al. (2009) to model attitudes toward spending, which were not incorporated into the Blekesune and Quadagno article. Using more current data also ensures that the political and social events that have occurred since 1995 are incorporated in the answers of respondents.

\subsubsection{Dependent Variables}

I ask how attitudes toward public pensions and unemployment benefits differ between individuals and countries as measured by belief about government spending. Therefore, I have selected two dependent variables best fit to answer these questions. The survey items used to derive these variables state:

Listed below are various areas of government spending. Please show whether you would like to see more or less government spending in each area. Remember that if you say 'much more', it might require a tax increase to pay for it. More or less government spending on: old age pensions, unemployment benefits.

Chioce set were originally, 'spend much more', 'spend more', spend the same as now', 'spend less', 'spend much less'." The differences between stating 'much more' and 'more' and between 'much less' and 'less' are not are not clear in a cross-national context. 'Much more' money in the United Kingdom may be equivalent to 'more' money in Sweden. Another problem with the original response categories is that to answer the current research 
questions, it is only important to understand if people favor spending more, spending the same as now, or spending less than is currently being spent on public pensions and unemployment. Given these issues, the two dependent variables that ask about attitudes toward spending are collapsed from five categories into three response categories: those who think spending should increase, those who feel it should stay the same as now, and those who think it should be increased.

To make sure that country spending levels were not influencing the relationship between country-level differences in spending attitudes, I conducted a preliminary analysis to address any cofounding effects. While I found that social spending in these countries differed significantly, this difference does not explain or affect the magnitude or direction of any of the reported results. The regression models include country-level dummies to account for country specifics, such as spending levels, which can cause different intercepts (following the work of Busemeyer, Goerres, \& Weschle, 2009). Given that the spending dependent variable has three response categories, I use generalized ordered logistic regression to model the relationship between attitudes toward spending and public pensions (table 3) and attitudes toward spending and unemployment (table 4). I have chosen generalized ordered logistic regression to avoid violations of the parallel lines assumption.

\subsubsection{Independent Variables}

Based on previous literature and available data, several independent variables at the individual-level are used to test self-interest and political ideology. The operationalization of these variables is discussed in table 1: Description of Variables. To evaluate the validity of the impact of self-interest on attitudes toward public pensions, I examine five independent variables: age, gender, self-reported social class, education, and employment status. I measure political ideology in two ways: in terms of political party identification and egalitarian attitudes regarding the role of government. To measure political party identification, I use three dummy variables: right leaning (referent), left leaning, and other or no party. Respondents who answered "Other" could have either left or right leanings, as is true for people who said they did not have a political party. Eglaitarian attitude has been used in other studies examining welfare state attitudes in Europe (see Blekesaune and Quadagno, 2003, for example). Descriptive statistics for each variable are located in table 2.

Table 1. Description of Variables, International Social Survey Role of Government Survey (2006)

Dependent Variables Definition of Variables

Government Spending on Pensions

Response to question that asks if the government should increase, decrease or spend the same amount on retirement for the elderly. Spend less $=0$, spend same $=1$, spend more $=2$

Response to question that asks if the government should increase,

Government Spending on Unemployment decrease or spend the same amount on unemployment programs. Spend less $=0$, spend same $=1$, spend more $=2$

\section{Self Interest Independent Variables}

Age

Gender

Education

Employment

Subjective Social Class

Political Ideology Independent Variables

Political Party ID

Egalitarian Attitudes
Continuous variable representing respondents age, ranging from 18-94

"Sex of respondent". Dummy coded: female $=1$, male $=0$

"Comparative: highest completed degree of education". Dummy coded: college degree or higher $=1$, lower than a college degree $=0$

"Currently in paid work" coded: Employed = currently working, Unemployed = not currently working, but looking for employment, Retired = formally paid work, now retired, No labor status = housewife, student, or other not in the labor force.

Response to question: "What social class do you belong (TOPBOT)?" Ranging from 0 (lowest) to 10 (highest). Recoded: working (0-3), middle (4-7), and upper (8-10). Based on Bean and Papadakis, 1998.

"Comparative: Political ideology" Left-leaning, Right-leaning, Other/no party (Other includes: other, no specific, and no party preference, which are combined by ISSP and cannot be separated) "Government should reduce income differences between rich and poor." Should =1, should not=0. 
Table 2. Descriptive statistics for independent and dependent variables, International Social Survey Role of Government (2006)

\begin{tabular}{lcccc}
\hline Dependent Variables & Mean & S.D & Min & Max \\
\hline Government Spending on Pensions & 0.485 & 0.595 & 0 & 2 \\
Government Spending on Unemployment & 1.002 & 0.709 & 0 & 2 \\
\hline Self Interest Independent Variables & & & & \\
\hline Age & 49.004 & 16.400 & 18 & 94 \\
Gender (Female) & 0.578 & 0.499 & 0 & 1 \\
Education & 0.396 & 0.489 & 0 & 1 \\
Employment & 2.283 & 0.946 & 0 & 3 \\
Subjective Social Class & 0.870 & 0.687 & 0 & 2 \\
\hline Political Ideology Independent Variables & & & & \\
\hline Political Party ID & 0.995 & 0.853 & 0 & 2 \\
Egalitarian Attitudes & 0.654 & 0.476 & 0 & 1 \\
\hline
\end{tabular}

\subsection{Analytical Technique}

I use a generalized ordered logistic regression model with clustering on the country-level to answer my research questions. Ordered logistic regression allows me to compare those who feel spending is too high (referent) to the other two response categories (spend the same as now, or spend more). Therefore, instead of contrasting two groups against each other, I compare one group to the other two groups. Odds ratios and robust standard errors are presented as the results for attitudes about government spending on public pensions and unemployment.

I conducted separate regression models for each of the dependent variables, because measuring different features of the welfare state in the same model could undermine the differences between the attitudes. Logistic regression (logit) analysis is a multivariate technique that allows for estimating the probability of whether or not an event occurs by predicting a dependent outcome from a set of independent variables. Therefore, logistic regression uses the log odds of the dependent variable, and not the variable itself, to calculate change. For the purposes of interpretation, I convert the logit into a statement about the odds ratio of the dependent variable by using the exponential function (see Mau, 2005, for further description). The logit models for each dependent variable are set up in the same manner. In every model, I use social democratic countries as the referent countries. Liberal and corporatist/conservative countries are then included as country-level dummy variables. I also test country-level variation using liberal countries as the referent to test for significant differences between liberal and conservative/corporatist countries (results not shown but available upon request). Model one tests the self-interest theory with the correlating variables, model two tests the political ideology variables with the correlating variables, and model three combines models one and two as a way of testing both theories simultaneously. Odds ratios showing support for the function and financing of the welfare state are then reported in tables 3 and 4.

\section{Results and Discussion}

Often, simple ordinal logistic regression odds ratios are used to compare different answer choices by, in effect, estimating a summary odds ratio using a weighted average of two odds ratios. To use ordinal logistic regression correctly, however, the data must not violate the proportional/parallel odds assumption, which states that all of the implicit comparisons yield the same odds ratio (Hoffman, 2004). This is impractical given the current data, so I use a variation of ordinal logistic regression called generalized ordered logistic regression (Williams, 2006). The first panel of the results table shows odds ratios of predictors which differentiate between the answer "less spending' versus 'same as now' and 'more spending'. The second panel shows odds ratios of predictors, which differentiate between 'less spending' and 'same as now' versus 'more spending. Busemeyer et. al. (2009) explain it in terms of the difference between respondents on the first step of a ladder and the second and third steps of a ladder in panel one. In panel two it is the difference between the people on the third step and the first two. In stata, this is done using the 'gologit2' command. 


\subsection{Country-level Results for Spending on Public Pensions}

The country-level results for attitudes about spending on public pensions are interesting, but slightly unpredictable theoritically. There is a significant difference between all of the regime types when spending less is compared to spending the same and spending more on pensions. This relationship is shown in table 3 ; and it is also true when the reference category is changed from social democratic regime to the conservative regime. At the second level, where spending less and same is compared to spending more, conservative countries still have significantly different attitudes compared to social democratic countries, but the difference between liberal and social democratic countries is no longer significant. Given the previous literature, I expected social democratic countries to be the least likely to support cuts in spending on public pensions. However, I find that people in liberal countries, the United States and the United Kingdom, are the less likely to state that they want less spending on pensions compared to the same as now or more. People in conservative countries have the highest odds of supporting cuts (less spending) to public pension programs, followed by social democratic countries and then liberal countries. The question is, what makes respondents in liberal countries less likely to support cuts to public pensions than even those in the very generous social democratic countries? One answer might involve recent challenges that public pensions have faced in both the United States and the United Kingdom. Pensions have been threatened or reduced (in the UK), which has made these citizens more aware that public pensions could be in danger of cuts. Interestingly, corporatist's countries have significantly different attitudes in both panels. This means that corporatist countries are always more likely than social democratic countries to support reducing spending on public pensions.

\subsection{Country-level Results for Attitudes on Spending on Unemployment}

I do not find clear ideological differences when applying traditional regimes to attitudes toward unemployment spending. These results are shown in table 4. In model one and model three, liberal countries have significantly lower odds of supporting less spending on unemployment than social democratic countries. However, the significance of this relationship is only evident in panel one of the results. In panel two, the only difference on the country-level using traditional regimes is in model three where corporatist countries have significantly (at the .10 level) higher odds of supporting less spending on unemployment compared to social democratic countries. When liberal countries are used as the reference category, results show that the liberal regime is significantly different from both the social democratic regime and the conservative regime. Therefore, I find that the liberal regime is always significantly different from the other two regimes when spending less is compared to spending the same/more. But, I do not find much support that social democratic countries have different overall attitudes than conservative countries.

\subsection{Individual-level Results for Attitudes on Spending on Pensions}

Table 3 shows the results for attitudes about government spending on public pensions. In model one, when respondents were asked if the government should spend more on pensions, about the same as they do now, or less, in both panels females have significantly lower odds than males of agreeing with the idea of less spending. Age is not a significant predictor of attitudes. This seems to fit well with Anderson's (2002) findings. He found that while age was a predictor of attitudes for some programs, it was not for pensions. The other variable that is significant in both panels of model one is education. Having a college education or higher is associated with much higher odds of supporting a decrease in government pension spending. In panel one, several employment variables are significant. However, retired respondents do not have significantly different attitudes than those currently in the labor force. As mentioned previously, retirement should be a good indicator of self-interest because these are the respondents who are most likely to be benefiting from public pensions in the sample. The unemployed, however, and those with no labor status were significantly less likely to support spending cuts.

In model two, political ideology variables are examined. Compared to right leaning respondents, left-leaning respondents were slightly less likely to ask for less or the same spending on pensions as opposed to more spending. Also, respondents with more egalitarian attitudes are 73 percent less likely to support spending cuts than those with less egalitarian attitudes. In model three, the full model, gender and education are again both significant in both panels and in the same direction as previously discussed. Interestingly, age becomes significant in panel two. This means that the older people get, the less likely they are to agree on less spending or the same as now compared to more spending. 
Table 3. Generalized Ordered Logistic Regression, Attitudes about Spending on Public Pensions

\begin{tabular}{|c|c|c|c|c|c|c|}
\hline \multirow{2}{*}{$\begin{array}{l}\text { Models of policy spending } \\
\text { preferences on Elderly } \\
\text { Spend less vs. Same as now/more } \\
\text { spending }\end{array}$} & \multicolumn{2}{|c|}{ Model 1: Self Interest } & \multicolumn{2}{|c|}{ Model 2: Political ID } & \multicolumn{2}{|c|}{ Model 2: Full Mode } \\
\hline & Odds Ratio & $\begin{array}{l}\text { Robust } \\
\text { std. err. }\end{array}$ & Odds Ratio & $\begin{array}{l}\text { Robust } \\
\text { std. err. }\end{array}$ & Odds Ratio & $\begin{array}{l}\text { Robust } \\
\text { std. err. }\end{array}$ \\
\hline Female & $.827 * * *$ & 0.024 & & & $0.863 * * *$ & 0.018 \\
\hline Age & 0.988 & 0.008 & & & 0.988 & 0.008 \\
\hline Education (College+) & $2.236 * * *$ & 0.135 & & & $2.134 * * *$ & 0.14 \\
\hline \multicolumn{7}{|l|}{ Class (upper) } \\
\hline Working & 0.791 & 0.121 & & & 0.835 & 0.114 \\
\hline Middle & 1.109 & 0.149 & & & 1.063 & 0.119 \\
\hline \multicolumn{7}{|l|}{ Employment (employed) } \\
\hline Unemployed & $0.617 * *$ & 0.096 & & & $0.675^{* *}$ & 0.105 \\
\hline Retired & 0.909 & 0.137 & & & 0.947 & 0.133 \\
\hline No labor status & $0.843 * * *$ & 0.037 & & & $0.868 * *$ & 0.044 \\
\hline \multicolumn{7}{|l|}{ Party (right) } \\
\hline Left & & & $0.813+$ & 0.097 & $0.798^{* *}$ & 0.083 \\
\hline Other & & & 0.95 & 0.118 & 0.941 & 0.085 \\
\hline Egalitarian Attitude & & & $0.438 * * *$ & 0.029 & $0.512 * * *$ & 0.044 \\
\hline \multicolumn{7}{|l|}{ Welfare State Regime } \\
\hline Corporatist & $1.696 * * *$ & 0.174 & $1.696 * * *$ & 0.174 & $1.817 * * *$ & 0.158 \\
\hline Liberal & $0.574 * * *$ & 0.082 & $0.574 * * *$ & 0.082 & $0.551 * * *$ & 0.061 \\
\hline \multicolumn{7}{|l|}{ Less + Same vs. More } \\
\hline Female & $0.552 * * *$ & 0.024 & & & $0.587 * * *$ & 0.02 \\
\hline Age & $0.987 * *$ & 0.006 & & & $0.978 * *$ & 0.008 \\
\hline Education (College+) & $2.074 * * *$ & 0.224 & & & $1.944 * * *$ & 0.2 \\
\hline \multicolumn{7}{|l|}{ Class (upper) } \\
\hline Working & 0.816 & 0.411 & & & 0.873 & 0.422 \\
\hline Middle & 1.27 & 0.637 & & & 1.202 & 0.569 \\
\hline \multicolumn{7}{|l|}{ Employment (employed) } \\
\hline Unemployed & 0.849 & 0.249 & & & 0.933 & 0.246 \\
\hline Retired & 0.898 & 0.261 & & & 0.947 & 0.264 \\
\hline No labor status & 0.765 & 0.134 & & & 0.793 & 0.139 \\
\hline \multicolumn{7}{|l|}{ Party (right) } \\
\hline Left & & & $0.717 * *$ & 0.098 & $0.714^{* *}$ & 0.085 \\
\hline Other & & & 0.953 & 0.231 & 0.929 & 0.194 \\
\hline Egalitarian Attitude & & & $0.421 * * *$ & 0.042 & $0.524 * * *$ & 0.07 \\
\hline \multicolumn{7}{|l|}{ Welfare State Regime } \\
\hline Corporatist & $2.591 * * *$ & 0.148 & $2.367 * * *$ & 0.256 & $2.793 * * *$ & 0.12 \\
\hline Liberal & 1.659 & 0.534 & 1.502 & 0.583 & 1.611 & 0.503 \\
\hline
\end{tabular}

Significance: $* * * \mathrm{p}<.001 ; * * \mathrm{p}<.005 ; * \mathrm{p}<.05 ;+\mathrm{p}<.10$

4.4 Individual-level Results for Attitudes on Spending on Unemployment

Table 4 shows the results for attitudes about spending on unemployment. Like the previously discussed attitudes toward spending on pensions, three response categories are examined. In the first panel of the table, those who responded 'less spending' are compared to those who stated 'same spending as now' or 'more spending'. In panel two, those who responded 'less spending' or 'same as now' are compared to those who stated 'more spending'. Therefore, higher odds ratios show stronger support for spending less on, or cutting support for, unemployment programs.

In model one, self-interest variables are tested. In both panels, gender, age, class, and employment are significant predictors of attitudes toward spending on unemployment. Females have significantly lower odds of agreeing with the idea of less spending than males. As age increases, so do the odds that someone will disagree with the idea that less spending should be spent on unemployment. Those in the upper class are more likely to support less spending on unemployment than either those in the working class or the middle class. This supports the self-interest theory because those in working or middle classes are more vulnerable if they lose their job, and thus more likely to need unemployment benefits. Lastly, the unemployed have much lower odds of supporting cuts to unemployment programs. This is the most persuasive argument when it comes to the self-interest theory. The self-interest theory asserts that people have more favorable attitudes toward programs they will directly 
benefit from. The unemployed, compared to the employed, are qualified to receive these specific benefits.

In model two, political ideology variables are tested. Compared to those who identify as 'right' leaning politically, those who are 'left leaning' or in the other catagory have lower odds of supporting reduced spending on unemployment. Also, those with egalitarian attitudes have lower odds of supporting reduced spending on unemployment. This is true for both panels. Therefore, model two demonstrates support for the political ideology theory and in the direction that would be expected given previous research.

Model three combines the two theories into the full model. In model three, unemployment status, working class status, and age remain significant for predicting attitudes about spending for unemployment. This is consistent with some previous findings (Busemeyer et al. 2009). The political ideology variables also maintain their significance and direction in the full model.

Table 4. Generalized Ordered Logistic Regression, Attitudes about Spending on Unemployment Programs

\begin{tabular}{|c|c|c|c|c|c|c|}
\hline $\begin{array}{l}\text { Models of Spending for } \\
\text { Unemployed }\end{array}$ & Model 1: & elf Interest & Model 2: & olitical ID & Model 2: & ull Model \\
\hline $\begin{array}{l}\text { Less vs. Same as } \\
\text { now/more }\end{array}$ & $\begin{array}{l}\text { Odds } \\
\text { Ratio }\end{array}$ & $\begin{array}{l}\text { Robust std. } \\
\text { err. }\end{array}$ & $\begin{array}{l}\text { Odds } \\
\text { Ratio }\end{array}$ & $\begin{array}{l}\text { Robust std. } \\
\text { err. }\end{array}$ & $\begin{array}{l}\text { Odds } \\
\text { Ratio }\end{array}$ & $\begin{array}{l}\text { Robust std. } \\
\text { err. }\end{array}$ \\
\hline Female & $0.883^{*}$ & 0.053 & & & 0.931 & 0.07 \\
\hline Age & $0.989 * * *$ & 0.003 & & & $0.989 * * *$ & 0.002 \\
\hline Education & & & & & & \\
\hline (College+) & $1.967 * * *$ & 0.196 & & & $1.876 * * *$ & 0.175 \\
\hline Class (upper) & & & & & & \\
\hline Working & $0.359^{* *}$ & 0.118 & & & $0.368^{* *}$ & 0.14 \\
\hline Middle & $0.521^{*}$ & 0.177 & & & $0.456^{*}$ & 0.185 \\
\hline $\begin{array}{l}\text { Employment } \\
\text { (employed) }\end{array}$ & & & & & & \\
\hline Unemployed & $0.254 * * *$ & 0.039 & & & $0.281 * * *$ & 0.041 \\
\hline Retired & 1.154 & 0.155 & & & $1.224+$ & 0.137 \\
\hline No labor status & $0.605^{* *}$ & 0.104 & & & $0.637 * *$ & 0.115 \\
\hline Party (right) & & & & & & \\
\hline Left & & & $0.356 * * *$ & 0.091 & $0.356 * * *$ & 0.091 \\
\hline Other & & & $0.472 * * *$ & 0.043 & $0.580 * * *$ & 0.047 \\
\hline Egalitarian Attitude & & & $0.354 * * *$ & 0.039 & $0.381 * * *$ & 0.044 \\
\hline Welfare State Regime & & & & & & \\
\hline Corporatist & 1.141 & 0.398 & 1.026 & 0.494 & 1.204 & 0.467 \\
\hline Liberal & $0.497 * * *$ & 0.064 & 0.612 & 0.268 & $0.439 * * *$ & 0.057 \\
\hline Less + Same vs. More & & & & & & \\
\hline Female & $0.730 *$ & 0.086 & & & 0.785 & 0.082 \\
\hline Age & $0.979 * * *$ & 0.002 & & & $0.979 * * *$ & 0.002 \\
\hline Education & & & & & & \\
\hline (College+) & 1.212 & 0.149 & & & $1.118 * * *$ & 0.128 \\
\hline Class (upper) & & & & & & \\
\hline Working & $0.311 * * *$ & 0.087 & & & $0.336^{*}$ & 0.103 \\
\hline Middle & $0.441 * *$ & 0.104 & & & 0.400 & 0.109 \\
\hline $\begin{array}{l}\text { Employment } \\
\text { (employed) }\end{array}$ & & & & & & \\
\hline Unemployed & $0.323 * * *$ & 0.099 & & & $0.361 * * *$ & 0.120 \\
\hline Retired & $1.187+$ & 0.120 & & & 1.229 & 0.110 \\
\hline No labor status & $0.706^{*}$ & 0.115 & & & $0.748 * *$ & 0.119 \\
\hline Party (right) & & & & & & \\
\hline Left & & & $0.318 * * *$ & 0.061 & $0.313 * * *$ & 0.104 \\
\hline Other & & & $0.626 * * *$ & 0.037 & $0.614 * * *$ & 0.127 \\
\hline Egalitarian & & & & & & \\
\hline Attitude & & & $0.502 * * *$ & 0.042 & $0.535 * * *$ & 0.061 \\
\hline Welfare State Regime & & & & & & \\
\hline Corporatist & 1.757 & 0.612 & 1.868 & 0.878 & $2.025+$ & 0.843 \\
\hline Liberal & 0.702 & 0.162 & 1.068 & 0.620 & 0.701 & 0.807 \\
\hline
\end{tabular}

Significance: $* * * \mathrm{p}<.001 ; * * \mathrm{p}<.005 ; * \mathrm{p}<.05 ;+\mathrm{p}<.10$ 


\subsection{Ancillary Analyses}

Using the Intra-class correlation statistic, the variation at the country compared to the individual-level can be measured. For government spending on pensions 11 percent of the variation in attitudes happens at the country-level while 58 percent occurs within countries at the individual-level. For government spending on unemployment, 14 percent of the variation in attitudes occurs at the country-level while 65 percent percent occurs at the individual-level.

\subsection{Discussion}

This paper has examined attitudes about spending on public pensions and unemployment using generalized ordered logistic regression that includes multiple levels addressing both individual and country-level differences. While addressing the question, "Do attitudes about government spending on pensions and unemployment vary by regime type?", I find support for Esping-Andersen's typology regarding attitudes about spending on pensions, but I find less support for this typology relating it to unemployment, partically supporting my first hypothesis. This could be because Esping-Andersen focused on pensions to develop his typology. It would make sense, given the amount of previous research debating the application of this typology to attitudes, that it cannot easily be applied to unemployment. Perhaps this can be explained by something other than policy feedback and tradition that is shaping attitudes about spending on some welfare programs, specifically unemployment. In other words, at the national level there is something that affects attitudes about policies that cannot fully be explained by individual characteristics (because they are controlled for) or previous constructions of similarities between countries.

While being unemployed is a significant predictor of attitudes toward spending on unemployment insurance (and for that matter, attitudes on pubic pension spending), retirement does not act as a significant predictor of attitudes toward public pensions. These findings support a portion of my second hypothesis. Age, however, is a significant predictor of attitudes toward pensions when spending less or the same is compared to spending more. Given these results, I think the self-interest theory is supported, but perhaps not as strongly as expected. This suggests that the type of welfare program may determine how well self-interest theory can predict attitudes. Universal programs are not as well served by this theory as targeted programs. Political ideology variables are significantly related to attitudes toward government spending, and those who have more leftist political ideas are more likely to support increased spending than those who favor the right. This finding supports my third hypothsis. In the case of political ideology, however, attitudes toward targeted programs are better explained than attitudes toward universal programs. In summary, people do not think about government spending on pensions and unemployment in the same way; therefore, attitudes cannot be generalized across welfare state programs.

As mentioned, I add three major ideas to the literature on welfare state attitudes. Attitudes toward unemployment and pensions are not the same and cannot be assumed to be. Esping-Andersen's typology can, in fact, be applied to attitudes with minimal variation especially as it pertains to pensions. Self-interest and political ideology theories both impact individual-level differences in attitudes; while these theories measure different ideas of influence, they are both important in understanding peoples' attitudes about social policies. These findings are important given the amount of welfare restructuring that has occurred and continues to occur. As governments find new ways to cut welfare state spending, the opinions of the people who will benefit from those programs should be heard and understood within a larger context. This paper takes a step in that direction.

\section{Acknowledgements}

I would like to thank Jill Quadagno, Karin Brewster, Jason Barbas, Sara Dixon and Deana Rohlinger for comments and suggestions on this manuscript.

\section{References}

Anderson, S. (2002). Assuring the stability of welfare to work exits: The importance of recipient knowledge about work incentives. Social Work, 4(2), 301-314. http://dx.doi.org/10.1093/sw/47.3.301

Andreß, H. J., \& Heien, T. (2001). Four worlds of welfare state attitudes? A comparison of Germany, Norway, and the United States. European Sociological Review, 17(4), 337-356. http://dx.doi.org/10.1093/esr/17.4.337

Arts, W., \& Gelissen, J. (2002). Three worlds of welfare capitalism or more? A state-of-the-art report. Journal of European Social Policy, 12(2), 137-158. http://dx.doi.org/10.1177/0952872002012002114

Bean, C., \& Papadakis, E. (1998). A comparison of mass attitudes towards the welfare sate in different institutional regimes, 1985-1990. International Journal of Public Opinion Research, 10(3), 211-236. 
http://dx.doi.org/10.1093/ijpor/10.3.211

Breznau, N. (2010). Economic equality and social welfare: Policy preferences in five nations." International Journal of Opinion Research, 22(4), 458-484.

Blekesaune, M., \& Quadagno, J. (2003). Public attitudes toward welfare state policies: A comparative analysis of 24 nations. European Sociological Review, 19(5), 415-427. http://dx.doi.org/10.1093/ijpor/edq024

Brooks, C., \& Manza, J. (2007). Why Welfare States Persist: The importance of Public Opinion in Democracies. Chicago: University of Chicago Press. http://dx.doi.org/10.7208/chicago/9780226075952.001.0001

Busemeyer, M. R., Goerres, A., \& Weschle, S. (2009). Attitudes towards redistributive spending in an era of demographic ageing: the rival pressures from age an income in 14 OECD countries. Journal of European Social Policy, 19(3), 195-212. http://dx.doi.org/10.1177/0958928709104736

Canaan, R. A., Hasenfeld, Y., Canaan, A., \& Rafferty, J. (1993). Cross-cultural comparison of attitudes toward welfare-state programs: Path analysis with log-linear models. Social Indicators Research, 29(2), 123-152. http://dx.doi.org/10.1007/BF01077892

Cook, F. L. \& Jacobs, L. R. (2002). Assessing assumptions about American's attitudes toward social security” In P. Edelman, D. L. Salisbury \& P. J. Larson (Eds.), The Future of Social Insurance: Incremental Action or Fundamental Reform? (pp. 82-110). Brookings Institution Press: Washington, D.C.

Esping-Andersen, G. (1990). The Three Worlds of Welfare Capitalism. Cambridge: Polity Press.

Esping-Andersen, G., \& van Kersbergen, K. (1992). Contemporary research on social democracy. Annual Review of Sociology, 18,187-208. http://dx.doi.org/10.1146/annurev.so.18.080192.001155

Gelissen, J. (2000). Popular support for institutionalized solidarity: A comparison between European welfare states. International Journal of Social Welfare, 9, 285-300. http://dx.doi.org/10.1111/1468-2397.00140

Hasenfeld, Y., \& Rafferty. J.A. (1989). The determinants of public attitudes toward the welfare state." Social Forces, 67, 1027-1048

Hicks, J. R. (1999). A reconsideration of the theory of value. In J. Cunningham-Wood \& M. McLure (Eds.), Critical Assessments of Leading Economists. New York: Routledge.

Jackman, M. R. (1994). The Velvet Glove: Paternalism and Conflict in Gender, Class, and Race Relations. Los Angeles: University of California Press.

Jacoby, W. G. (1994). Public attitudes toward government spending.” American Journal of Political Science, 38, 336-361. http://dx.doi.org/10.2307/2111407

Jæger, M. M. (2006). Welfare regimes and attitudes towards redistribution: the regime hypothesis revisited. European Sociological Review, 22, 157-170. http://dx.doi.org/10.1093/esr/jci049

Korpi, W., \& Palme, J. (1998). The paradox of redistribution and strategies of equality: Welfare state institutions, inequality, and poverty in the western countries. American Sociological Review, 63(5), 661. http://dx.doi.org/10.2307/2657333

Lewis, J. (1988). “Gender and the development of Welfare Regimes.” Journal of European Social Policy, 2(3), 159-173. http://dx.doi.org/10.1177/095892879200200301

Linos, K., \& West, M. (2003). Self-interest, social beliefs, and attitudes to redistribution. Re-addressing the issue of cross-national variation. European Sociological Review, 19, 393-409. http://dx.doi.org/10.1093/esr/19.4.393

Lynch, J., \& Myrskyla, M. (2009). Always the third rail? Pension income and policy preferences in European $\begin{array}{llll}\text { democracies. } & \text { Comparative } & \text { Political } & \text { Studies, }\end{array}$ http://dx.doi.org/10.1177/0010414009331722

Marx, K. (1927). Capital: A critique of political economy. (F. Engles, Ed., S. More and E. Aveling Trans.) (3 ${ }^{\text {rd }}$ ed.). Chicago: Charles H. Kerr and Company.

Mau. S. (2005). Democratic demands for a social Europe? Preferences of the European citizenry. International Journal of Social Welfare, 14, 76-85. http://dx.doi.org/10.1111/j.1369-6866.2005.00344.x

O’Conner, J., Orloff, A. S., \& Shaver, S. (1999). States, Markets, Families: Gender, Liberalism and Social Policy in Australia, Canada, Great Britain and the United States. Cambridge: Cambridge University Press

Pontusson, J., \& Rueda, D. (2010). The politics of inequality: Voter mobilization and left parties in advance 


$$
\text { industrial states." } \quad \text { Comparative } \quad \text { Political } \quad \text { Studies, } 435 \text { 405. }
$$
http://dx.doi.org/10.1177/0010414009358672

Quadagno, J., \& Pederson, J. (2012). Has support for social security declined? Attitudes toward the public pension scheme in the USA, 2000 and 2010. International Journal of Social Welfare, 21, S88-S100. http://dx.doi.org/10.1111/j.1468-2397.2012.00877.x

Svallfors, S. (1997). Words of welfare and attitudes to redistribution: A comparison of eight western nations. European Sociological Review, 13, 283-304. http://dx.doi.org/10.1093/oxfordjournals.esr.a018219

---. (2004). Class, attitudes and the welfare state: Sweden in comparative perspective. Social Policy and Administration, 38(2), 119-138. http://dx.doi.org/10.1111/j.1467-9515.2004.00381.x

Weber, M. (1921/1968). Economy and society. (G. Roth and C. Wittich, Trans.). New York: Bedminister.

Williams, R. (2006). Generalized ordered logit/practical proportional odds models for ordinal dependent variables. The Stata Journal, 6(1), 58-82.

\section{(c)) EY}

This work is licensed under a Creative Commons Attribution 3.0 License. 